\title{
5: 68498669-68509826
}

National Cancer Institute

\section{Source}

National Cancer Institute. 5: 68498669-68509826. NCI Thesaurus. Code C41881.

Physical location of CCNB1_Gene 